University of Michigan Law School

University of Michigan Law School Scholarship Repository

Articles

Faculty Scholarship

8-1982

\title{
The Coming Curtailment of Compulsory Child Support
}

David L. Chambers

University of Michigan Law School, dcham@umich.edu

Follow this and additional works at: https://repository.law.umich.edu/articles

Part of the Family Law Commons, Juvenile Law Commons, Law and Society Commons, and the Legislation Commons

\section{Recommended Citation}

Chambers, David L. "The Coming Curtailment of Compulsory Child Support." Mich. L. Rev. 80 (1982):

1614-34.

This Response or Comment is brought to you for free and open access by the Faculty Scholarship at University of Michigan Law School Scholarship Repository. It has been accepted for inclusion in Articles by an authorized administrator of University of Michigan Law School Scholarship Repository. For more information, please contact mlaw.repository@umich.edu. 


\title{
COMMENT
}

\section{THE COMING CURTAILMENT OF COMPULSORY CHILD SUPPORT}

\author{
David L. Chambers*
}

\begin{abstract}
Absent parents ought to contribute to the support of their minor children and states can appropriately invoke the force of law to compel them to do so. Stated so generally, even absent parents behind in their payments would probably agree. Since so many others agree as well, and since the numbers of single-parent children have mushroomed, systems of governmentally compelled support in this country have grown enormously. By the early part of the next century, if current laws remain in force and current population trends continue, most of America's children on any given day will be entitled to support from a parent who no longer lives with them or never lived with them at all.
\end{abstract}

At some distant point in the future, however, American states and other Western nations may greatly curtail their systems of compulsory support. Two forces have informed the current schemes of private liability. The first is a perception, wholly accurate, of large numbers of children in need - children who cannot be adequately provided for by the single parent with whom they live. The second is a moral judgment about the obligations of parents. States may alter the laws of child support if there ceases to be a substantial number of children considered to be in need or if changes occur in the perception of the degree of moral responsibility absent parents bear for their children's support.

Changes of the second sort seem particularly likely, despite the steady increase over the past decade in public fervor to collect support. A paradox of the current era is that while everyone acknowledges that absent parents should support their children, so few parents actually do so except under threat of jail. Today, this resis-

* Professor of Law, University of Michigan Law School. A.B. 1962, Princeton University; LL.B. 1965, Harvard University.-Ed.

Some of the ideas in this comment first appeared in inchoate form in the final chapter of an empirical study of the enforcement of child support today, D. Chambers, Makino Fathers PAY (1979). The comment is a substantially expanded version of an essay that will appear in The Parent Child-Support Obligation: Research, Practice and Social Policy (J. Cassetty ed., forthcoming 1982). 
tance is widely considered immoral. It will never be commended, but for reasons to be explored, it may someday be condoned and grudgingly accepted, like the incidence of divorce itself. If accepted, states may eventually limit orders of child support to only a few years' duration and, in certain circumstances, eliminate the obligation altogether.

Prediction is always risky. Recall America in 1910. Only the most apocalyptic of people then living would have forecast today's rate of divorce or the numbers of children whose parents never live together at all or current attitudes toward sexuality or the altered role of government, especially the federal government, in meeting people's needs for income. If we could glimpse the year 2050, we would surely experience the same sensation of beholding Sodom and Gomorrah.

Here nonetheless is a forecast of some of the changes that may occur over time in the conditions and beliefs that affect the shape of systems of child support. ${ }^{1}$ I am neither a demographer nor an economist. On the other hand, whether my predictions prove accurate matters little for purposes of this essay. Like Orwell or Bellamy, my purpose in portraying the future is to cast light on the present. I seek to examine some existing conditions that are widely known but deserve to be seen in a different light and that raise serious doubts about a system - compulsory payments by absent parents throughout their children's minority - the justifications for which few of us have ever questioned.

\section{Conditions That Affect Laws of Support}

\section{A. The Number of Children in Financial Need}

Today, the great majority of single-parent children live with their mothers, and most such families are poor. In 1978, over half the children living in families maintained by women with no husband present lived below the federal poverty line even after taking into account welfare benefits they received. ${ }^{2}$ Even those children whose mothers earned enough to keep them above the poverty line typi-

1. Many volumes have been published in recent years that examine changes that have occurred and may occur in family structure and changes in law or other social institutions that may (or ought to) accompany the changes in the family. Some of the more stimulating accounts are J. Bernard, The Future of Marriage (1972); M. Glendon, The New MarRIAGe aNd THe NeW Property (1981); K. Keniston, All Our ChILdRen (1977); S. LeVITAN \& R. Belous, What's Happening to the AMERICAN Family? (1981); Family IN Transition (A. Skolnick \& J. Skolnick eds. 1971).

2. Bureau of the Census, U.S. Dept. of Commerce, Special Studies, Series P-23, No. 104, AMERICAN FAMIlies AND Living ARRANGEMENTS 16, chart 27 (1980). 
cally lived at a lower standard of living than they could have if their other parent had been living with them.

Will there be a decline in the numbers of single-parent children in need? Probably not in the short run. With the aid of a group of statisticians, Daniel Patrick Moynihan, the Senator from New York, has recently made some projections that will carry us to the beginning of the next century. ${ }^{3} \mathrm{He}$ has forecast that of all children born in 1978 , roughly half will have lived in a one-parent, female-headed family before reaching eighteen and that of that group, two-thirds (or roughly one-third of all children) will receive Aid to Families with Dependent Children before reaching eighteen. Those are striking figures, each approximately fifty percent higher than the figures for children born in the early 1960 's and reaching majority today. ${ }^{4}$

Moynihan's projections were based on trends in the rates of nonmarital births and divorce and on the rates of participation of single-parent families in the AFDC system. In the short and long term, the number of children in need will also turn on other factors, many of which Moynihan could hardly have tried to take into account: the nation's general prosperity, the rate of use of contraceptives, the incidence of abortion, the birth rate generally, the degree of women's participation in the labor force, the relationship of men's earnings to women's, the incidence of father-custody and joint custody, and changing notions of the concept of need.

As to a few of these, we are already beginning to see trends that may lead to a reduction of the number of children in need: for example, a greater and greater percentage of women raising children on their own have jobs outside the home - about sixty-five percent in 1980.5 On the other hand, as to some other relevant factors very little change has yet occurred, even though many have expected it. For example, neither the proportion of single-parent families headed by men $^{6}$ nor women's average earnings as a percentage of men's average earnings, ${ }^{7}$ has grown over the past few decades.

Whether or not Moynihan's projections for the year 2000 prove wholly accurate, it is highly probable that then, as now, most singleparent children will live with their mothers, that a great many such

3. Moynihan, Children and Welfare Reform, 6 J. INST. Socioecon. STUd. 1, 8 (1981). See also Glick, Children of Divorced Parents in Demographic Perspective, J. Soc. Issues, Fall 1979, at 170.

4. Moynihan, supra note 3, at 8.

5. Bureau of the Census, supro note 2, at 13.

6. Id. at 11 , chart 16 .

7. Bureau of Labor Statistics, U.S. Dept. of Labor, Handbook of Labor StatisTICS 118, table 60 (December 1980). 
mothers, especially those of the youngest children, will not be employed full time and that, even if they do work full time, they will earn less than most men. Some sort of income transfer system will surely continue to exist and it will probably remain a mixed public and private system - something comparable to the AFDC system and the current child-support system.

But what changes will have happened in the next fifty or seventyfive years? Given the mixed signals emitted by current statistics, many futures are plausible, but in one plausible future a point will come when young men and young women have roughly equal opportunities for employment and for advancement within employment and equal social support for lifelong participation in the labor force. Single individuals of either sex will be able to earn a decent level of income. Many Americans today strongly favor government policies to foster "full employment" and equal opportunity. If such changes in employment and opportunity do occur, either of two states of mind might evolve about children and their income needs. One is that a child can usually make do adequately with a single parent. The other, no less plausible, is that it takes the continual income of two parents to provide adequate support for a child. Which of these views will dominate will turn in part on the future cost of living. It will also turn on the perceptions of future generations about the "normal" life setting for children and the accompanying view of the moral responsibilities of absent parents for their children, an issue to which we are about to turn.

The issues of financial need and moral responsibility may seem separate but in fact intertwine. When we refer to children who meet AFDC standards, we employ a concept of "need" that is close to an absolute sense of that term. Yet people may well use the term in a different sense in the context of child support. They may perceive a child who has lived with both parents, both working, at a high standard of living but who now lives with one parent at a moderate standard as in "need," even if she currently lives at as high a standard as the mean of American children. On the other hand, if the higher standard of living she enjoyed when her parents lived together ceased to be seen as the norm to which she was entitled to aspire, she would no longer be an object of public concern. Whether we consider her in need turns on whether we consider her to have moral claims on the absent parent's income. 


\section{B. Changing Perceptions of the Appropriateness of Requiring Payments from the Long-Absent Parent}

The reasons we demand support from parents may seem so selfevident as to require no explanation. We invoke the tautology that the child is, after all, "their" child. We allude to thousands of years of human history in which a man and a woman have lived with their children under a single roof and have shared in the task of assuring that the children's needs are met. But, however reasonable the grounds for assuming (and requiring) that parents who live with a child support the child, the reasons are substantially more brittle for imposing long-term financial liability on a parent who has never lived with a child or who once lived with a child but has not so lived for many years. The reasoning may seem increasingly brittle over the coming decades. Two sorts of justifications are offered today for rules imposing liability on parents for the care of their child: that they caused the child to come into being and, more broadly, that they are part of the child's relevant "family." 8 Let us look briefly at these two grounds and the changes in our perceptions about each that may occur over time.

\section{The Responsibility of Those Who Bring Children Into Being}

One jurisprudential foundation for governmentally imposed child support is remarkably simple and straight-forward: parents cause children to come into being; they are capable of not causing children to come into being, by merely refraining from intercourse; having engaged in an act of their free will, they can justly be held responsible for the consequences. That's all there is to it. American courts and legislatures have relied on much the same reasoning to hold manufacturers responsible for injuries caused by their products.

Fifty years from now, there will have been many developments in the science of genetics and reproduction, but it is probable that most children will still result from voluntary intercourse between a man and a woman. If so, the same reasoning will remain available. It may nonetheless be less persuasive than it is today in those cases in

8. An alternative theory for holding partners in married couples liable is that post-separation child support is a part of the "contract" that they enter at the point of marrying. In large part, of course, the notion of a "contract" is a fiction, at least to the extent that contracting is used in the traditional sense of a voluntary meeting of the minds. The marriage contract in this sense is more like a contract of adhesion with the terms dictated by the state. The purpose of this piece is to explore afresh the terms the state may dictate in the future.

It is probably true that most couples who marry do have some common, loose expectations of what they can expect from each other; my guess, however, is that, at the point of marriage, few couples consider what to expect from each other if they divorce after having children. 
which the parents have had no more than a dating relationship and have never lived together. Such cases account for perhaps oneeighth of all children born today. 9 How later generations will consider the children of such relationships may well turn on what changes of attitudes occur toward abortion and sexuality.

Today we are in a period of national ferment over the issue of abortion. In the United States today, three of every ten pregnancies end in abortion, ${ }^{10}$ yet, at the same time, large numbers of people ardently believe abortion immoral. The moral attitudes of Americans fifty or a hundred years from now are difficult to foresee. Congress and the states may have adopted a constitutional amendment prohibiting abortion altogether. If that occurs, or if attitudes toward abortion remain in as much conflict as they are today, then attitudes toward the responsibility of each parent for a child may well remain the same.

On the other hand, it is possible that attitudes will have moved far to the other extreme. Abortion will be seen as a morally neutral act, just as during this century more and more Americans have accepted contraception as a morally neutral act. Abortion in the early months of pregnancy may have become nearly risk-free to the woman and freely available, perhaps through a nonprescription, overthe-counter pill. If that time arrives, then a pregnant woman, not living with the father, who knows that the father has no desire to participate in the child's upbringing may be seen as making a unilateral decision to bear a child and the responsibility for its birth and for raising it may be seen as hers alone. ${ }^{11}$ That view seems most

9. Bureau of the Census, U.S. Dept of Commerce, Statistical Abstract of the UNITEd STATES: 1981, at 65, table 98 [hereinafter cited as 1981 Statistical AbSTRACT]. Figures are available on numbers of children born outside of marriage but not on children born outside of living-together relationships. Today about one-sixth of births are to unmarried women. It is apparently the case, however, that most children born outside of marriage are not born to parents who live with each other.

10. In 1978, approximately 294 abortions were performed for every 1000 pregnancies that ended in either abortion or live birth, an increase of over 50 percent from the year 1973. 1981 STATISTICAL ABSTRACT, supra note 9, at 66, table 100. It is probable that the rate continued to grow after 1978, since it increased in every year from 1973 to 1978. A recent study published in the Journal of the American Medical Association indicates that the near elimination of federal funds for abortions has had little effect on the incidence of abortions performed on poor women. Cates, The Hyde Amendment in Action: How Did the Restriction of Federal Funds for Abortion Affect Low Income Women?, 246 J. A.M.A. 1109 (1981).

11. Rules turning on the mother's subjective beliefs about the father's intentions would impose almost insurmountable problems of proof. On the other hand, a flat rule denying support except when the parents had lived together would exclude many cases in which the mother reasonably believed that the father would play a role. Making the problem even more complex is the fact that, in the United States today, expectations about parental roles may differ widely by race and class. For a discussion of ties that survive between children and black, low income fathers who never lived with the children's mothers, see Furstenberg and 
likely to arise if, by this point in the future, most people believe what many already believe today: that an abortion is usually the wisest course for an unattached woman in this position. Before such views about abortion could develop, attitudes about intercourse, and especially nonmarital intercourse, might also have to change. People who regard nonmarital intercourse as sinful or as an act typically initiated by manipulative males who treat women as objects may well want to hold the male responsible regardless of the later decision-making process of the woman. Attitudes toward both nonmarital sex and abortion may well evolve in tandem, but where they will come out is difficult to guess.

If attitudes toward sex and abortion do become more permissive, then it is possible that the male, in the case of children conceived during a dating relationship outside marriage, will eventually be seen in much the same way as the contributor to a sperm bank is seen today. Few today would wish to hold liable the sperm bank donor, even though he is plainly the "cause" of a child having come into existence. Why not? Because someone else's voluntary decision to bear a child is seen as the relevant act for determining liability.

A rule of law in the future that turned on whether the mother reasonably believed the father would play a role in the childrearing would bear a disturbing resemblance to the discredited rules of the past that turned on a child's legitimacy, ${ }^{12}$ even though the new rule might in fact be framed in terms of whether the parents were living together at the point of conception and not on whether they were married. At a minimum, the rule would lead to similarly needy children being treated differently on the basis of factors outside the children's control. Such rules have often been criticized. While the child's lack of control over the parents' act may increase reluctance to change the rule, it need not do so as a matter of principle. In our society, except in unusual circumstances, children are bound by the

Talvitie, Children's Names and Paternal Claims, 1 J. FAM. Issues 31 (1980). See also C. STACK, ALL OUR KIN (1974).

At least one trial court judge has determined that the parents' states of mind may be relevant to the father's liability. In New York City, a woman tricked a celebrity into having intercourse with her, telling him she was using the pill, but actually hoping to conceive. A trial judge held that the man had been deceived and took the deception into account, ordering him to pay some support, but less than the usual amount because his net worth and income were so much higher than the mother's. In re Pamela P., 7 FAM. L. REP. (BNA) 2784 (N.Y. Fam. Ct. Oct. 8, 1981). Recently, an appellate court rejected the father's claim altogether and raised the amount of support ordered. According to a news account, the court's opinion stated that even if the father was deceived, "how does it logically follow that the child should suffer?" N.Y. Times, July 4, 1982, at 18, col. 6. (1981).

12. See H. Krause, Child Support in America: The Legal Perspective 115-62 
actions of their parents. It's one of the consequences of being a child within a family. The important question is not whether the children are similarly needy but whether there is a just claim against the parent one wants to hold liable.

\section{The Responsibility of "Family" Members}

The preceding section suggests that changing attitudes toward abortion might alter people's sense of the appropriateness of holding a father financially responsible in cases in which a woman chooses to carry a fetus to term knowing that the father does not want the child and has no desire to participate in raising the child. Parents involved in the common cases of divorce, however, are in a quite different position. Their children, as well as the children of some couples who have lived together over an extended period, are typically the product of a joint decision or at least the product of a complex set of mutual expectations. For them there is more than the "causal link" to justify holding the absent father liable; there is also the link of the parents and child having lived together as family. There are many examples of laws imposing liability on one relative for another when only this link of family tie has been present.

Over the last hundred years, state laws in this country have at various times imposed financial liability on adults for their aged parents, on grandparents for grandchildren, and even on adult siblings for each other. ${ }^{13}$ These laws have rested not on a judgment of moral fault and certainly not on a relative's having caused a baby to be born but rather on a strong sense that "family" should take care of itself. As notions of core "family" have altered, most of these laws have been repealed.

Today, in the public mind, a child's only relevant "family" for purposes of financial responsibility is his mother and father, wherever they live and whether they live together or not, until majority, death, or the entry of a court order terminating parental rights. Most people do not regard the financial responsibility of a parent when he lives with a child to be markedly different from his responsibility years after he has moved away.

In the future, it is possible that this view of responsibilities will be held even more confidently than it is today. Recent research suggests that, in intact families, children form strong attachments to (1968).

13. H. Clark, The LaW of Domestic Relations in the United States $§ 6.7$, at 212-18 
both their fathers and their mothers at an early age. ${ }^{14}$ It also suggests, though the evidence remains disputed, that married fathers in intact families are gradually becoming more involved in childrearing tasks. ${ }^{15}$

If these sorts of trends continue, it is conceivable that more divorcing parents will choose shared custodial arrangements. It is even conceivable that the rate of divorce itself will decline. And even if single custody remains the norm and the divorce rate remains high, fathers, if more involved with their children during marriage, may strive to sustain closer visiting relationships afterwards. It may also be thought important to strive to sustain such closer relationships. Some adults may come to view the single parent family as complete, but children, at least children of divorce, will still view their family as broken. Several recent studies of divorced children living with their mothers suggest that one factor related to children's emotional health and development after divorce is the quality of their continuing relationship with their fathers. ${ }^{16}$

On the other hand, it is possible that a very different view of the family will evolve over time, a view in which absent parents will command a much smaller place than they do today. We may be in a period of transition in which family includes both blood ties and ties to people with whom one lives in intimacy. In the future, however, large numbers of people may regard the family solely as the group of people who live together in intimacy at a given point in time, whether or not related by blood or marriage. So seen, a stepparent or stepsibling would be regarded as part of a child's relevant core "family" and the stepparent would be held financially responsible for his or her stepchild during the period when they reside together. On the other hand, a blood parent who never lives with a child (like many fathers of children born outside of marriage) and a parent who once lived with a child but has long ago moved elsewhere, would no longer be seen as part of a child's relevant family at all or would be so seen for only a brief period of time. Commentators would cease to use the preseparation standard of living of the mother, father and child as the relevant touchstone for deciding whether the new unit of

14. The Role of the Father in Child Development (M. Lamb ed. 1976); The FaTHER-INFANT RELATIONSHIP (F. Pedersen ed. 1980).

15. J. Robinson, Changes in Amerucans' Use of Time: 1965-1975 (1977).

16. J. Wallerstein \& J. Kelly, SuRviving the BREAK-UP 171-72, 203, $217-19$ (1980); Hess \& Camara, Post-Divorce Family Relationships as Mediating Factors in the Consequences of Divorce for Children, J. Soc. Issues, Fall 1979, at 79. Like nearly all studies of children of divorce, the studies cited here suffer from the lack of random sampling. For a thoughtful appraisal of Wallerstein and Kelly, see the review by C. Bruch, 79 MrCH. L. Rev. 708 (1981). 
one parent and child has enough income. ${ }^{17}$ Such changes in the concept of family might well not be good for children, any more than the increase in the rate of divorce itself has been good for children. That's just the way it would be.

Will such a change of view in fact come about? The principal messenger for such a change has been around for many years. It is the actual response of absent parents to obligations of child-support and opportunities for visitation. Without great prodding, most parents who have never lived with their children - most typically, fathers who are the subject of paternity suits - never pay support at all. Even divorced fathers who have lived with their children typically pay regularly for only a short time, then pay less, and then often pay nothing. ${ }^{18}$ In the United States in 1975, of five million mothers living with minor children and divorced, separated, remarried or never married, only about one fourth received child support payments of any kind during the year and, of those who received anything, fewer than half received thirty dollars or more a week. ${ }^{19}$ Neither love nor a sense of moral responsibility induces most absent parents to pay as much as they could.

Current patterns of visitation are similar. Most fathers of children from outside of marriage do not see their children at all. Every study of divorced, noncustodial fathers confirms a pattern somewhat comparable to their patterns of payment of support: visits begin with frequency and then typically taper off within a few years. Frank Furstenberg has recently completed a study of a representative national sample of children aged seven to eleven from intact and separated families. ${ }^{20} \mathrm{He}$ found that of children living with their mothers whose parents had never been married, sixty-six percent had not seen their fathers in at least a year. He found a rate not much lower for those children living with their mothers after di-

17. See, e.g., D. Chambers, Making Fathers Pay 37-68 (1979); Weitzman, The Economics of Divorce: Social and Economic Consequences of Property, Alimony and Child Support Awards, 28 UCLA L. REv. 1181, 1235-41 (1981).

18. See Chambers, Men Who Know They Are Watched: Some Benefits and Costs of Jailing for Nonpayment of Support, 75 MrcH. L. REv. 900 (1977); K. Eckhardt, Social Change, Legal Controls, and Child Support: A Study in the Sociology of Law (1965) (Ph. D. dissertation, University of Wisconsin).

19. See Bureau of the Census, U.S. Dept. of Commerce, Current Population Reports, Special Studies, Series P-23, No. 84, Divorce, Child Custody, and Child SupPORT 12, table 7 (1979).

20. F. Furstenberg, The Life Course of Children of Divorce: Marital Disruption and Parental Contact (paper presented at meeting of the Population Association of America, San Diego, 1982. A digest of the paper will appear in Family Planning Perspectives forthcoming 1982). See also Furstenberg, Recycling the Family: Perspectives for a Neglected Family Form, MARR. \& FAM. REV., Fall 1979, at 1. 
vorce: fifty-two percent of such children had also not had contact with their father in at least a year. In the divorce cases, the longer it had been since the parents' separation, the less likely it was for the father to visit with the child. Many others who research divorced families report similar patterns. ${ }^{21}$ Furstenberg found that the strongest two factors available to him to predict whether visitation occurred were whether the mother or father, and especially the father, had remarried. ${ }^{22}$ The vast majority of divorced men and women do remarry. In the United States today, about half do so within three years. (The percentages are even higher if living-together relationships outside of marriage are taken into account.) Somewhat surprisingly, women with children are as likely to remarry as women without. ${ }^{23}$

Many people attribute noncustodial parents' low rates of payment and visitation to indifference to their children's welfare. It is nonetheless possible to ascribe more sympathetic causes for declining feelings of responsibility over time. Although a minority of divorced, noncustodial fathers sustain a vital relationship with their children years after separation, many fathers who see their children no more frequently than once a week or every other week find the visitation relationship unnatural and unsatisfying. Over time, they feel less and less a part of their children's lives. ${ }^{24}$ Especially if the custodial parent remarries, but even if she does not, most noncustodial parents participate less and less in the tiny events important to the sense of family, the events that make one feel the child's protector, teacher and companion. Over time, many fathers come to regard child support as a form of taxation without representation.

If the noncustodial parent remarries, he develops a new center for his life and derives satisfactions from new children with whom he shares life day-to-day. In Furstenberg's words, the father's remarriage "frequently introduced new parental obligations . . . weakening his ties with his biological offspring. In effect, [in these cases] sociological parenthood took precedence over biological

21. W. GoOde, Women In Divorce 315-16 (1956); J. Wallerstein \& J. Kelly, supra note 16, at 236; Hetherington, Cox \& Cox, Stress and Coping in Divorce: A Focus on Women, in Psychology aNd Women: IN TRANSition 95 (J. Gullahom ed. 1979); Fulton, Parental Reports of Children's Post-Divorce Adjustment, J. Social Issues, Fall 1979, at 126, 133.

22. F. FURSTENBERG, supra note 20.

23. Koo \& Suchindran, Effects of Children on Women's Remarriage Prospects, $1 \mathrm{~J}$. FAM. IssuEs 497 (1982) (overall average the same, some variation by age of women at divorce).

24. J. Wallerstein \& J. Kelly, supra note 16, at 236, 238; R. Weiss, Marital SEParaTION 187-98 (1975); Hetherington, Cox \& Cox, Divorced Fathers, 25 FAM. CoORDINATOR 417, (1976). 
parenthood."2s Such fathers would surely still say that they loved their child from the previous marriage, but the feelings are not the same as they were.

Over the coming decades, it is possible that most divorced, noncustodial parents will become even more detached from their children by a previous relationship than they are today. What will affect them - so subtly that they will be unaware of it - is the ever-increasing incidence of children living with only one of their parents. We have seen a great change in the last thirty years from a view of divorce as a form of social pathology to a view of divorce as simply an unpleasant fact of twentieth century life. In 1960, on any given day, about twenty-two percent of all children under eighteen in the United States lived in a home without one or both of their biological parents. By 1978, the figure had risen to thirty-two percent and, by 1990, according to estimates of the Bureau of the Census, the figure will have risen to around forty-one percent. ${ }^{26}$ Early in the next century, if the same trend continues, half of America's children on any given day will be living with neither blood parent or with only one. When that day arrives, it seems likely that family units of one parent and children, perhaps with a stepparent, will more and more be seen as a complete "family" unto themselves. If a single parent and child living alone are "family," then the long absent parent is even more likely to regard his financial responsibilities as diminished or ended - and his perceptions of his responsibilities are more likely to become accepted as reasonable.

An even more global force is at work. An adult woman living alone with children can survive at a higher standard of living today than was possible in the past. There are still major economic disincentives for a woman with children to leave her husband, since she is highly likely to suffer a severe decline in income. But it is at least possible for her to live on her own, even with children, without starving. Indeed, the rise in the rate of divorce during the century has been attributed in part to women's increased economic opportunities. ${ }^{27}$ If the trend continues of more and more women participating as full-time workers in the labor force during marriage, our economy is likely increasingly to facilitate short-term adult relationships for

25. F. Furstenberg, supra note 20.

26. Bureau of the Census, supta note 19, at 11, chart 16.

27. See H. Ross, \& I. Sawhill, Time of Transition: The Growth of Families HeADED BY WOMEN 62 (1975); Scanzoni, A Historical Perspective on Husband-Wife Bargaining Power and Marital Dissolution, in DrvoRCE AND SEPARATION 20-36 (G. Levinger \& O. Moles eds. 1979). 
both men and women: individuals who spend their adult lives with a series of partners separated by periods of living alone. Marriage itself may increasingly be viewed as a tentative commitment to be continued only so long as it serves both parties' emotional needs. Eventually, people may come to regard each individual adult as the society's base unit of production and consumption and the unit of either one or two adults and a child as the wholly normal setting for a child's upbringing. Such discontinuous family arrangements may produce changes in children's development, changes some would regard as harmful, but, within some limits, adult needs and the pressures of economic forces, not children's needs, determine family patterns in this world. As changes occur, what is good for children is conveniently redefined.

\section{Implications for Future Public Policies}

\section{A. Why Laws May Stay the Same}

Here then are two plausible futures: noncustodial parents maintaining closer ties with their children than is common today; or noncustodial parents drifting farther away and gradually seen as less and less relevant to their children's lives. Possibly, both will exist side by side - with divorcing couples who have shared childrearing responsibilities most commonly exhibiting the first pattern and unmarried parents who never lived together and parents who did live together but retained largely segregated roles in marriage exhibiting the second.

Today, though the second pattern, the pattern of perpetual or eventual disengagement, describes the position of more than half of the noncustodial parents, public acceptance of long term responsibility for support remains firm. Current laws will probably remain in place for many years to come. They are likely to continue to reflect the moral sensibilities of many people. They also display our best instincts as a society that cares about its children. Support laws are especially unlikely to change so long as many single parents live in poverty. Even if most taxpayers come to understand, even sympathize with, the declining sense of involvement many absent parents feel, it will require future enormous changes in notions of individual responsibility and the proper role of government before they will decide to tax themselves for all the costs of supporting the children. Such a shift may seem unlikely but would in fact be no more revolutionary than the shifts in notions of familial responsibilities that have 
already occured in this century and have produced such programs as Social Security and Supplemental Security Income.

A second source of resistance to change may rest on views of children's psychological needs. If policy makers come to share the view of some social scientists that continued contact between children and their absent parents serves important psychological values for the children, ${ }^{28}$ they may find that compulsory child support helps sustain some absent parents' sense of a stake in their children. Furstenberg has found a strong relationship between support payments by absent fathers and visitation: children whose fathers pay child support regularly tend to visit regularly. ${ }^{29}$ On the other hand, he is appropriately cautious about the causal link between the two phenomena. If further studies indicate that parents are substantially more likely to continue visiting when successfully prodded into maintaining payments of support, then sound reasons would exist for retaining present laws.

A final factor that may serve to keep current laws in place is the matter of gender. It is impossible today to think intelligently about attitudes toward obligations of support or to predict developments over time without considering matters of gender, for gender affects both perceptions of need and perceptions of responsibility. Today, the overwhelming majority of children who live with only one of their parents live with their mothers. The anger that many mothers and other women express when fathers fail to pay is often directed not merely at the moral irresponsibility of individual men but also at the social and economic position in which they view themselves as having been placed by men or "society" in general.

To appreciate the place of gender in shaping attitudes toward child support, picture the position today of an American father with custody of his children. As an initial matter, we typically view him as being in his position by choice. Society has not prescribed childrearing as his lot in life. Few would have depicted him as a deserter if he had failed to seek custody of his children at the time of the divorce. He also typically stands in a different position economically. Upon becoming a single parent, he is far less likely to be entering the labor market for the first time and far more likely to have attained substantial seniority in his employment. Moreover, as a man, he is likely to earn over 60 percent more at his job, regardless of his years of seniority. ${ }^{30}$ In Michigan and apparently in other

28. See note 16 supra and accompanying text.

29. F. Furstenberg, supra note 20; see also D. ChAMBERs, supra note 17, at 127-29, 332 (1979) (reporting a similar finding on incomplete data).

30. See Bureau of Labor Statistics, supra note 7, at 118, table 60. 
states today, judges often enter no order of support against the mother in father custody cases, even when the mother is employed. ${ }^{31}$ Of course, in such cases, there may be reasons for the judges' behavior other than a belief that the father can adequately provide for the children, but if women today were in the position men are - able in general to provide support for their children, regarding themselves as custodians by choice - there might well be far less public concern about securing support from absent parents.

To be sure, many divorcing men today also see themselves as victims of their gender - discriminated against with regard to custody, evicted from the homes they strained for years to earn enough to buy. ${ }^{32}$ Many men resent being viewed as privileged for their position in the labor force. Life repairing streets or tightening bolts on an assembly line isn't all pleasure. Men are over three times as likely as women to be injured in job-related accidents. ${ }^{33}$ And job-related and role-related stress probably explain in part why men in the United States live substantially shorter lives than women. ${ }^{34}$ But as to child support women are justly perceived as the principal victims.

So long as women remain economically disadvantaged, a substantial system of private income transfers is likely to remain in place. Over the next few decades, I hope that support will be collected in more efficient, less punitive, ways than it is today. Our current enforcement system is shaped too much by anger. Today, even in those states which take enforcement seriously, the most common method of collection is to wait until a person under an order of support receives his wages and then try to scare or cajole him into payment by the threat of jail. ${ }^{35}$ I have elsewhere recommended that child support be collected through a national system of wage deductions, such as the federal and state governments use today for income and social security taxes. ${ }^{36}$ Wisconsin is giving serious consideration to adopting such a system on a state-wide basis. ${ }^{37}$ I hope we move toward it as a nation.

31. D. Chambers, supra note 17 , at 15.

32. See diatribes such as R. DoYLe, The RAPE of the MALE (1976) or M. FranKs, How To Avold ALIMONY (1975).

33. See 1981 Statistical AbStract, supra note 9, at 118, table 190.

34. 1981 Statistical ABSTRACr, supra note 9, at 69, table 105.

35. D. Chambers, supra note 17, at 71-162.

36. Id. at 258-61.

37. See Garfinkel, in The Parent Child-Support Obligation: Research Practice and Social Policy (J. Cassety ed., forthcoming 1982). 


\section{B. How Laws May Change}

Many millions of noncustodial parents in the future are likely to be wholly detached psychologically from their children. If attitudes toward that detáchment soften, what changes in the law can be expected? Many - and they range from mild to radical. Let's consider them briefly in ascending order.

Some modest changes are possible even today while general attitudes about parental responsibilities remain confidently fixed. A few could be adopted (and are already being adopted in some places) that simply respect those occasions in which both parents accept the detachment that has occurred. States are beginning to recognize more explicitly the right of couples to agree by contract to vary otherwise applicable obligations of support. 38 Another change, closely analagous, would be appropriate in the increasing number of states in which public agencies participate in collecting support on behalf of parents not receiving welfare benefits. ${ }^{39}$ More and more agencies are now set up to monitor payments and enforce orders without awaiting complaints from the custodial parent. Such "selfstarting" enforcement systems can greatly increase levels of payments under current systems. ${ }^{40}$ They are also impersonal. At a minimum, such systems - and any national wage deduction system of the form I support - should be implemented in a way that honors requests from custodial parents in non-welfare cases that they would rather not have an order enforced. ${ }^{41}$ Such requests may come in cases in which the mother would prefer that the father leave her and the children alone and she and the father have reached an informal agreement that he need not pay if he does not visit. Such agreements may be harsh on children, but government ought to stay out of these voluntary arrangements between parents. Intervention seeking to compel a continued relationship is likely to produce more harm than good.

Another set of changes in the law would alter responsibilities

38. See Schultz, Contractual Ordering of Marriage: A New Model for State Policy, $70 \mathrm{CAL}$. L. Rev. 204, 280-88 (1982); L. WeItzman, The Marriage Contract 347-52 (1981).

39. As a condition of receiving full reimbursement for the costs of the AFDC program, states must establish an agency to enforce child-support in all welfare and certain non-welfare cases. 42 U.S.C. $\$ 653(\mathrm{~b})$, (c)(3), 654(6) (1976).

40. D. Chambers, supra note 17 , at $90-97$ (1979).

41. Only with reluctance should rules be promulgated that make distinctions between families who are and who are not receiving welfare benefits. Nonetheless, a parent not receiving welfare benefits faces a loss of income when requesting an agency not to enforce a support order. A parent receiving welfare benefits making a similar request faces no such loss. This seems a significant enough distinction to justify a difference in rule. 
without regard to the joint wishes of the parties. They would nonetheless recognize to a greater extent actual changes in the social and economic positions of the parties over time. Today it is apparently the case in most states that when courts or agencies fix child-support awards, they typically consider two factors only: the number of children and the earnings of the noncustodial parent. ${ }^{42}$ The actual earnings of the other parent, the custodial parent, are not taken into account. To be sure, the modest percentages of noncustodial parents' earnings used today in fixing awards ${ }^{43}$ compel custodial parents to work full time if they wish to maintain their former standard of living and, in this important generalized sense, custodial parents' earnings are already taken into account in fixing child-support awards. In most states, however, the custodial parent can earn as much as he or she is able without any decrease in the size of the child-support award. New laws might provide that courts would enter support orders determined by the same formulae that they use today and that this figure would apply for the first few years of an order but that thereafter a "tax" would be imposed on the custodial parents' earnings. The order might, for example, be reduced by one dollar for every three dollars the custodial parent earned above a certain base. 44 In this way, in most families, the noncustodial parent's compelled contribution would decline after a few years.

As a major step beyond, states might also eventually begin to take into account in some fashion the economic effects of new relationships of both adults. Thus, they might require courts to recompute order sizes to take into account not merely the income earned by the custodial parent but also the income of any new partners of the custodial parent. They might also adjust orders downward to reflect newly assumed financial obligations of the noncustodial parent for a new spouse or new children. ${ }^{45}$ Such rules would accommo-

42. See, e.g., D. Chambers, supra note 17, at 38-42 (reporting in Michigan and Seattle, Washington). See also schedules printed in H. KRAUSE, CHILD SUPPORT IN AMERICA: ThE Legal Perspective 12-13 n.37 (1981).

43. In a family with two children, the common support award in Michigan was around 30 . $35 \%$ of the father's net income. D. Chambers, supra note 17, at 40 . In Los Angeles, a study by Lenore Weitzman found the common order size for two children was around 25\%. Weitzman, supra note 17 , at 1233 . Weitzman and J. Cassetty have found that, as fathers' incomes rise, the percentage of their income awarded as child support declines. Weitzman, supra note 17; J. Cassetty, Child Support and Public Policy 64-65 (1978).

44. See chapters of Bergman and Sawhill, in The Parent Child-Support Obligation: Research, Practice \& Social Policy, supra note 37. Almost no state laws fix a formula for determining support. Most employ language expansive enough to permit the custodial parent's income to be taken into account today. The Uniform Marriage and Divorce Act expressly includes the custodial parent's resources among the factors that must be taken into account. See UNIForm Marriage and Divorce ACT \& 309.

45. See the recommendation of the British Committee on One-Parent Families. Great 
date the actual needs of all parties, even though they would also have the undeniable function of ratifying as legally significant certain stepparental relationships that the law has largely ignored. Stepparents today live in a legally and socially ambiguous relationship to their stepchildren. ${ }^{46}$ Perhaps some of the ambiguities inhere in the nature of the relationship. Later generations may conclude, however, that it is important to treat these relationships as fully as important as blood parent ones or even recognize them as largely superseding blood parent ones in those cases in which a stepparent lives with a child. 47

Rules taking into account some stepparental relationships for child-support purposes will cause practical problems. They will be cumbersome to administer if recomputations based on several persons' incomes must occur annually. They may also discourage forms of behavior, such as custodial parents' reattachment or remarriage, that states may wish to foster or at least avoid impeding. Over time, under certain circumstances, an even more radical change in the law may thus seem appropriate. Assume that at some future point, the great majority of children living with single parents have only occasional contact with their absent blood parent. (We are not far from that point today.) Assume also that a few years after birth or separation, the substantial majority of custodial parents, either on their own income or on a combination of their own income and the income of a new partner, are able to sustain a reasonable standard of living. (For the half of custodial parents who reattach themselves to another person within that period we are near that point today. We are not near that point for custodial mothers who do not remarry.) Assume finally that women in general consider themselves to have achieved equality with men in the labor force. (We are far from that point today.) If those points arrived, state legislatures might consider moving to reduce altogether the number of years of financial liability of the absent parent.

Today, orders of support run throughout a child's minority, lasting an average of about fifteen years in divorce cases and nearly

Britain Department of Health and Soclal Security, Report of the Committee on ONE-PARENT FAMILIES $\$ 5.225$ (1974).

46. See Mead, Anomalies in American Postdivorce Relationships, in DIvorce AND AFTER 107 (P. Bohannon ed. 1971).

47. I do not foresee a time when all stepparent relationships are treated as relevant for computing support. Only the income of those stepparents (or new partners) actually living with a child would be considered, for it will be only those stepparents who are considered part of the child's "family." Thus, orders would be reduced when the custodial parent and children begin to live with a new partner who earned a substantial income, but orders would not be raised when the noncustodial partner began to live with a high-earning partner. 
eighteen years in paternity cases. In most cases of divorce the orders last nearly twice as long as the marriages they follow. 48 In many cases of paternity orders, the orders run nearly as many years into the future as the young parents have lived up to this point themselves. Under the change in the law, orders of support might run for only three or four years, except, perhaps, in cases in which the custodial parent was physically disabled. Court-ordered visitation might also expire at the same point. Thereafter, payments and visitation would be encouraged but, like Christmas gifts or visits from grandparents, not enforced by government action. Parents could hammer out their own informal arrangements - or hammer out formal ones which courts would enforce if the parents chose to enter into them.

In some families in this future world - more families than today - the parents at the point of divorce would devise joint custodial plans with small transfers of income that would continue by agreement after the three-year period. In others, one parent would retain custody, but the other would continue to pay support voluntarily in much the same manner that many noncustodial parents do today in states where support orders lie largely unenforced. But after a few years, in most other families, all links, legal and social, between the absent parent and his children would end.

Orders of shorter duration would reflect a recognition in law of the psychological disengagement over time of most absent parents from their children. Such orders would also respond to the most pressing financial needs of children, since, in this future economy I have hypothesized, the difficulties custodial parents face in providing adequate support will typically be most urgent when the children are infants or, in cases of divorce, in the period immediately after separation. After a period of a few years, say three or four, the vast majority of custodial parents would work at full-time, decently compensated jobs or have reattached themselves to a full-time worker, or both. They would also have recovered emotionally from the period of greatest difficulty - the first year or two after separation..$^{49}$

A change in the law to reduce the years of liability would closely resemble a change that is occurring in judicial practices regarding

48. In a study of divorced couples with children in Genesee County, Michigan, the average age of the couples' youngest child was 3.3 years at separation. Thus a support order would be expected to last over 14 years. The average length of the marriages to the point of separation was 7.7 years. See D. Chambers, supra note 17, at 311, table 3I.

49. See J. Wallerstein \& J. Kelly, supra note 16, at 149-60; Hetherington, Cox, \& Cox, Effects of Divorce on Parents and Children in Nontraditional Families (M. Lamb ed., forthcoming 1982). 
alimony. It has apparently become less common than it once was for courts to enter orders of support of indefinite duration for nonworking wives even after fifteen or twenty year marriages and increasingly common for them to enter orders to provide support and funds for schooling or training for a fixed period of years. ${ }^{50}$ After that point, the former spouse might or might not have returned to her prior standard of living - probably not if she had remained single - but the expectation is that she at least will have become capable of supporting herself at a reasonable standard. Child-support may come to be viewed in much the same way: aid during a period of transition until the custodial parent can achieve financial independence or enter a new relationship.

Would such a drastic limit on orders of child support be appropriate today? Absolutely not. Just as alimony for only a short term seems inappropriate in many cases of long-term marriages in which it is ordered today, shortening the length of child support orders will be inappropriate so long as large numbers of custodial parents cannot afford to support their children at a reasonable standard of living either from their own incomes or from a decently funded public system of income maintenance or social insurance of a sort that does not currently exist.

If, however, changes in financial conditions or social programs occurred, such a change in the law would be wise even if it meant that some children a few years after divorce would have less income available to them than they do under the current system. It would probably be wise even if that minority of children who maintained regular contact with an absent parent seemed happier or better adjusted than the children who lost contact with their father and even if in some modest number of cases enforced support produced more regular visits. It would be wise in part because of an as yet unexpressed virtue of the curtailment of liability. That is the virtue of removing government from coercive involvement in people's lives. Americans today decry big government but are quick to use it to suppress undesired behavior. Child-support laws today fix for men and women the terms of their relationship many years after their lives have settled into other patterns. They are doing so for more and more families every year. Half the children born in the United

50. The Uniform Marriage and Divorce Act, parts of which have been adopted in many states, directs courts in fixing the amount and duration of alimony (which the act calls "maintenance") to consider "the time necessary to acquire sufficient education or training to enable the party seeking maintenance to find appropriate employment." UNIFORM MARRIAGE AND DIVORCE ACT § 308(b)(2). 
States today can expect to be eligible for an order of support for their benefit at some point during their childhood. Half can later expect, as adults, to be either the payor or payee of an order of support for their own children. The child-support system will reach perhaps two-thirds of all children born this year either as children or as adults.

If the current compulsory system continues, and continues in its current form, by the time many people reach their fifties, government will have been supervising their conduct or the conduct of their parents for over half the years they have been alive - sending warnings, threatening jailings, holding hearings on visitation. If children's basic needs could be met without compulsory support in the great majority of cases, it might be a better world - it would surely be a simpler one - if a few years after separation, adults were forced to work out voluntarily the terms of their relationships just as we require them to do today in nearly all matters when they live together. Of course, the value of removing government from people's lives would also be served by ending compulsory child support today, but to do so today would not merely cause financial privation, it would also force even more custodial parents and children into the welfare system, which, in its current form, provides its own highly intrusive form of government regulation of people's lives.

In many respects, the future I depict is bleak. There is nothing attractive about the increasing proportion of children who are born to single parents or the increasing incidence of the breakup of twoparent families. Single parents and recently divorced men and women are among America's least happy people. Children suffer greatly when their parents separate. It would be a better world if mothers, fathers and children stayed together, living happily ever after. It would probably be a better world if children whose parents never lived together or children whose parents lived together and separated sustained active ties to both parents throughout their childhood. I hope that is what the future holds. But if that is not what is going to happen, we should be reluctant to retain a system of government enforced nostalgia for a world that has been lost. 